\title{
Disasters and public health
}

M. F. LEChAT ${ }^{1}$

Studies on the health effects of disasters have shown that epidemiological indices can be of value in planning preventive and relief measures and in evaluating their effectiveness. Mortality rates naturally vary considerably, but in earthquakes, for example, the number of deaths per 100 houses destroyed can give an indication of the adequacy of building techniques. Age-specific mortality rates can help to identify particularly vulnerable groups and perhaps indicate what form of education would be valuable. Except in earthquakes, the number of casualties after a disaster is usually low in relation to the number of deaths, and study of the distribution and types of lesions would help in planning the amounts and types of relief supplies and personnel required. Disasters also affect the general level of morbidity in a district because of either interruption of normal health care services or of spraying or other disease control measures. Mental health and nutrition following disasters are particular problems that require further investigation. Study of all these features of disasters has been handicapped by a lack of data, particularly concerning the health situation immediately after the impact. The provision of surveillance teams in disaster-prone areas would appear to be a field in which international cooperation could yield immense benefits.

Over the last decade people concerned with public health have become increasingly concerned with natural disasters and their human consequences. There are a number of reasons for this. First, major disasters involving international aid are reported several times a year; as a result of better reporting by the mass-media, they appear to occur more frequently and they become more devastating as the population density in disaster-prone areas increases. Second, there is a strong feeling that nowadays disasters should be amenable to some kind of management to prevent them or mitigate their impact, or at least to improve rescue and relief.

Natural disasters can be defined as ecological disruptions exceeding the adjustment capacity of the affected community. They are of many types: earthquakes, floods, tidal waves, landslides, typhoons, volcanic eruptions. These are generally of sudden onset and imply unforeseen, serious, and immediate threats to public health. Droughts associated with famine, though they are predictable and develop slowly, may also be considered as natural disasters since they create similar problems requiring external assistance. There are many examples of such devastating events. In 1970, the top of the Huascaran mountain in Peru slipped into the Huaylas Valley engulfing several villages and killing tens of thousands of people in a matter of minutes. A few months later, approximately 250000 people died when a typhoon flooded the coastal area of East Pakistan (now Bangladesh). Earthquakes were responsible for 5000 and 25000 deaths in Managua (1972) and rural areas of Guatemala (1976), respectively, and perhaps three quarters of a million deaths in northern China in 1976. More recently, between 15000 and 25000 were provisionally reported as dead following the earthquake in Tabas, Iran, in September 1978.

${ }^{1}$ Professor, Centre de Recherche sur l'Epidémiologie des Désastres, Ecole de Santé publique, Université catholique de Louvain, Brussels, Belgium. 
In recent years there has been an increasing realization that the effects of natural disasters on the health of populations are amenable to study by epidemiological methods. Death rates can be computed for different types of disaster and attack rates can be calculated for the various types of disorder that occur in survivors, and indices of this sort can be used in planning appropriate measures for rescue and relief. There is also considerable interest at present in prevention, especially in the field of earthquake engineering, and such indices will provide essential tools for evaluating the effectiveness of various structural designs and building regulations in reducing death and injuries. The effectiveness of various types of assistance and the long-term effect of aid on the restoration of the pre-disaster situation could be assessed as well, if adequate pre-disaster information were available. This article discusses the various epidemiological indices relevant to disaster situations and their value in planning preventive and rescue measures.

\section{MORTALITY}

Death rates in disasters are highly variable, depending on a number of factors such as the type of disaster, the density and distribution of the population, conditions of the environment, degree of preparedness, and opportunity for warning. While the Yellow River floods in China in 1931 are said to have caused several million deaths, the earthquake in 1964 at Anchorage, Alaska, one of the severest ever recorded, claimed only 115 victims.

While death rates are of little or no use as an epidemiological indicator for the planning of relief and rescue, they are of considerable interest for evaluating the effectiveness of preventive measures aimed at mitigating the effects of disasters, especially in the case of earthquakes. The number of deaths per hundred houses destroyed in Turkey, a well-known area of tectonic instability, strongly points to some inadequacy in building techniques, making houses particularly lethal in this part of the world. The geographical distribution of damage and loss of life has not been uniform throughout the country, but has been higher in the east, despite a smaller population at risk in that part of the country. This may be due to the type of building material available, since, as one travels east, adobe (unburnt, sun-dried brick) is the main material used. In Iran, high death rates are associated with houses that are built of insufficiently reinforced adobe in which large concrete slabs are not properly supported.

High case-fatality rates from earthquakes are thus associated with the building techniques used in rural areas in certain countries. This highlights the need for control measures, such as appropriate building legislation and education, to reduce the number of deaths.

In other types of disaster, such as floods, the number of deaths may depend on early recognition of the impending disaster and on an appropriate warning system which allows the population enough time to leave the area or seek refuge. The timing of the warning is then all-important-whether to be on the safe side and run the risk of giving a false alarm, or to wait for definite signs of a disaster and risk giving the warning too late. The problem is similar to the dilemma of sensitivity versus specificity of methods of casedetection that is well known to epidemiologists and public health specialists involved in preventive medicine. The number of deaths may thus be used to check the adequacy of the criteria adopted for early warning of disasters.

Age-specific mortality rates after a disaster may also provide interesting insights into the reaction of the people at the time of impact. In Guatemala, following the 1976 earth- 
quake, age-specific mortality rates showed a bimodal profile. In the town of Patzicia (377 deaths) death rates above the overall rate of 3.5\% occurred among the 5-9 years age group (5.6\%) and among persons aged 60 years and over $(5.5 \%)$. A similar profile was obtained in the town of Sumpango (244 deaths). In both towns, the observed mortality was lower among infants and children 1-4 years old than in the 5-9 years age group, suggesting that parents took special care of their younger and more defenceless children. Following the Bangladesh cyclone in 1970, age-specific mortality rates also showed a bimodal, but different, distribution: $29 \%$ and $20 \%$, respectively, in the very young ( $0-4$ years) and over 60 years age groups. Data of this kind may thus identify disaster-vulnerable groups, and suggest ways in which appropriate education in communities exposed to natural disasters could reduce the number of deaths.

\section{POST-IMPACT DEATHS}

For obvious reasons, there is a lack of reliable information on the number of deaths in the first few minutes or hours after the impact. Surveys conducted among rescue workers on the use of drugs and equipment have shown how little is known about post-impact survival. However, from the relatively small numbers of serious casualties observed after most natural disasters (except for earthquakes) it seems as if people either die or survive relatively unhurt. These figures suggest that the severely injured perhaps die before rescue and emergency care become available.

In this respect, sociologists have conducted a number of studies that provide new insights into the reaction of communities and individuals to disasters. They show that within 30 minutes of a major disaster, up to $75 \%$ of the healthy survivors might actually be engaged in rescue activities. Such observations are most useful in preparing for disasters and increasing the effectiveness and acceptance of relief operations. Thus, in order to reduce the number of post-impact deaths the most efficient measure might be to train the local people in rescue techniques. Such training might involve the general community, or groups of volunteers, or organized professional groups, in order to increase the selfreliance of communities exposed to disasters. In certain areas, it might be feasible to train primary health care workers in disaster rescue and relief.

\section{MORBIDITY}

Except in earthquakes, the number of disaster casualties requiring medical attention is usually low in relation to the number of deaths. In floods, the proportion of people requiring medical care has been reported to vary between $0.2 \%$ and $2 \%$, most of the casualties having minor ailments such as skin lesions and ulceration. It has even been suggested that the general level of health among the survivors following a disaster could be better than that of the surrounding non-affected population. In Bangladesh, after the 1970 cyclone, the prevalence of disease and trauma was not any higher in the stricken districts than in the non-affected zones, the groups vulnerable to disease, that is those who were too young, too old, or too weak to hold on or take refuge, being lost in the storm.

The generally low impact-related morbidity rates, as well as the ratio of the number of injuries to the number of deaths (morbidity/mortality ratio), provide important indica- 
tions for planning the amount of relief supplies and personnel required. Experience in recent disasters has shown clear examples of overreaction, mobile hospitals of all kinds, teams of specialized surgeons as well as unprepared volunteers, and tons of useless supplies being rushed to the area, while other types of relief, and probably non-medical relief, would have been more appropriate.

Since, in earthquakes, it is believed that the number of injured may be linearly correlated with the number of deaths, death rates can also provide a rough estimate of the amount of relief required for the injured. In Guatemala, there were 3.4 injured persons for each death, and a similar ratio-of about 3-has been observed in several recent earthquakes in developing countries. The definition of a casualty is clearly important in this connexion: the number of casualties following the Huascaran tragedy in 1972, ranged from 4600 to 143000 (for approximately 70000 deaths) according to the definition used.

The type and distribution of lesions are also important in deciding on the resources required for relief, in particular following earthquakes. In Guatemala, fractures were predominant, especially fractures of the clavicle (about $12 \%$ in a survey of 157 patients), of the lower extremities (6\%), and of the spine and pelvis. Out of 75000 injured, 116 cases of total paraplegia were reported. Crush syndrome, though a well-known complication during the Second World War in people buried under debris for several hours, is apparently infrequent after earthquakes, no cases having been reported after the Guatemala earthquake (1976) and apparently very few after the Peru avalanche in 1970 and the Nicaragua earthquake of 1972. Burns, which in the past were the major hazard after an earthquake have been noticably absent in recent years, probably because adobe walls and tile roofs are difficult to ignite.

The pattern of complaints in people attending health facilities after a disaster may also provide useful information on the type of relief needed. Data collected in Guatemala showed that in less than a week the pattern of morbidity in the capital city had returned to the pre-disaster level, the emergency phase, that is the period of acute need for emergency primary care, being over within 7-8 days. Following the 1972 Nicaragua earthquake, this phase was over after day 5 , the types of patient seen in hospitals thereafter being similar to those in any general hospital during normal times. This return to normal may be much delayed, however, when the disaster strikes inaccessible human settlements, or where distrust of medical services or fear stop the injured people seeking appropriate care straight away. In Guatemala, for example, search parties found severely injured persons in far away localities as much as 20 days after the initial shock.

The monitoring of complaints in people seeking medical care in the days following a disaster is thus essential to the proper planning of health care in disaster situations, and must be related to the provision of field hospitals and specialized personnel. These generally arrive too late to actually take care of the impact-related casualties. In extreme but not exceptional cases, their main effect can even be to introduce for a temporary period a level of health care clearly incompatible with the local resources. Monitoring of the use of health facilities, especially hospitals, after a disaster, is therefore important. It requires the use of indices such as bed occupancy, duration of stay, and delineation of catchment area. This is especially important in order to improve preparedness for future disasters.

Effects on the prevalence and incidence of communicable diseases form another important aspect of disaster epidemiology. There may be increased transmission of diseases following the collapse of control systems (for example, interruption of insecticide spraying) and this aspect requires the implementation of a disaster-adapted epidemiological sur- 
Table 1. Indices proposed for assessing the health effects of natural disasters and the related needs

\begin{tabular}{|c|c|}
\hline Indices & Use \\
\hline \multicolumn{2}{|l|}{ Deaths } \\
\hline $\begin{array}{l}\text { number of impact-related deaths/population of } \\
\text { disaster area }\end{array}$ & $\begin{array}{l}\text { - rough assessment of the importance of the disaster } \\
\text { - evaluation of pre-disaster prevention or mitigation measures } \\
\text { - evaluation of adequacy of warning }\end{array}$ \\
\hline $\begin{array}{l}\text { number of impact-related deaths/population of given } \\
\text { age }\end{array}$ & $\begin{array}{l}\text { - identification of vulnerable groups for further contingency } \\
\text { planning }\end{array}$ \\
\hline $\begin{array}{l}\text { number of impact-related deaths/population within } \\
\text { given habitat or given location }\end{array}$ & $\begin{array}{l}\text { - vulnerability analysis of building structure or location for } \\
\text { improvement of preventive measures }\end{array}$ \\
\hline number of deaths/number of houses destroyed & — assessment of adequacy of building structures \\
\hline $\begin{array}{l}\text { number of impact-related deaths per unit of time after } \\
\text { the disaster/population of disaster area }\end{array}$ & $\begin{array}{l}\text { - determination of rescue measures required and evaluation of } \\
\text { rescue measures } \\
\text { - evaluation of self-reliance of community } \\
\text { - evaluation of pre-disaster community rescue training }\end{array}$ \\
\hline \multicolumn{2}{|l|}{ Casualties } \\
\hline number of deaths/number of casualties & $\begin{array}{l}\text { - determination of rough indices for estimating the numbers of } \\
\text { casualties (and emergency supplies required) in different types } \\
\text { of disaster }\end{array}$ \\
\hline number of casualties/population of disaster area & $\begin{array}{l}\text { - evaluation of pre-disaster and mitigation measures } \\
\text { - evaluation of adequacy of warning } \\
\text { - estimation of emergency care and relief needs }\end{array}$ \\
\hline distribution of types of casualty & $\begin{array}{l}\text { - estimation of emergency care and relief needs } \\
\text { - identification of risk factors for planning pre-disaster prevention } \\
\text { or mitigation }\end{array}$ \\
\hline \multicolumn{2}{|l|}{ Morbidity } \\
\hline number of consultations/surviving population & $\begin{array}{l}\text { - estimation of the type and volume of medical relief and resources } \\
\text { needed for immediate action } \\
\text { - evaluation and feedback regarding the relevance of relief given } \\
\text { - identification of remote population groups affected by the disaster } \\
\text { - gross assessment of health needs for further contingency planning }\end{array}$ \\
\hline time distribution of consultations & $\begin{array}{l}\text { - scheduling of medical relief } \\
\text { - identification of remote population groups affected by the disaster } \\
\text { - assessment of the profile of utilization of emergency and relief } \\
\text { care by local populations }\end{array}$ \\
\hline distribution of types of complaint & - identification of critical services to be maintained in emergencies \\
\hline incidence of communicable diseases & $\begin{array}{l}\text { - epidemiological assessment for establishing surveillance and } \\
\text { control measures } \\
\text { - identification of disaster-related risks of communicable diseases } \\
\text { for further contingency planning }\end{array}$ \\
\hline $\begin{array}{l}\text { hospital bed occupancy and duration of stay in } \\
\text { hospital }\end{array}$ & $\begin{array}{l}\text { - monitoring of health facilities and evaluation of the adequacy of } \\
\text { care }\end{array}$ \\
\hline geographical origin of hospitalized patient & $\begin{array}{l}\text { - assessment of needs for relief supplies including field hospjitals } \\
\text { and location of extra facilities }\end{array}$ \\
\hline
\end{tabular}

veillance system with appropriate indices and trends. The consequences of the disruption of routine health services in disaster situations as regards mortality and morbidity are often overlooked. Such effects are more relevant in urban areas and in developed countries. Recently, there have been cases where mortality from ischaemic heart disease, renal failure, and possibly from obstetric causes, have apparently been affected by the unavailability of normal health services.

Mental health is another recently identified and perhaps underestimated problem related to disasters, especially in urban areas. Studies are under way to assess the longterm impact on mental health of the Nicaragua earthquake. However, indices of mental 
health are hard to design, because of the large variety of cultural patterns found in the disaster-struck community and our ignorance about what should indeed be considered an adjusted reaction to disasters in exposed individuals.

Another major disaster-related problem is, of course, nutrition. It has been widely studied over the last 10 years, following the political uprising in Bangladesh, the civil war in Nigeria, and the droughts in countries south of the Sahara and in Ethiopia. Methods of nutritional assessment have been developed but the indirect effects of famine on the community extend much beyond the epidemiological field. The nutritional indices developed so far, such as weight-for-height, etc., consider only one facet of the problem. Malnutrition, and its corollary food aid, affect the population through a variety of mechanisms, which may range from effects on fertility and abortion, to price and market structures, and the distribution of wealth. Much more study is needed to develop appropriate measurements of the effects of malnutrition and to evaluate the appropriateness of various forms of food aid.

\section{COLLECTION OF DATA}

Studies on the effects of disasters on public health have been handicapped by the lack of epidemiological data. These could be collected either by conducting case studies of past disasters or by collecting factual information in the course of relief operations; this lack of on-the-spot assessments has definitely been a weak spot in the whole process of disaster management. Epidemiological surveys require the organization of assessment teams that can be activated rapidly after the disaster and, wherever possible, the teams should be composed of people from disaster-prone countries who are familiar with the particular area and the local customs. The organization of such stand-by epidemiological assessment teams seems to be one area in which international cooperation could yield immense benefits.

\section{RESUME}

\section{Les catastrophes et la santé publique}

Les catastrophes naturelles peuvent être définies comme des bouleversements écologiques qui dépassent les capacités d'adaptation des communautés qui en sont victimes. Leurs conséquences sur le plan de la santé publique sont dramatiques, que l'on considère le nombre de morts qu'elles entraînent ou leurs effets possibles à long terme sur la santé - par exemple recrudescence des maladies transmissibles en raison de la brusque interruption des mesures de lutte instaurées précédemment, troubles mentaux ou carences nutritionnelles. Un intérêt croissant s'est manifesté depuis quelques années pour une approche épidémiologique du problème des catastrophes. Il apparaît urgent de définir une série d'indices épidémiologiques relativement aisés à établir et qui pourraient servir à évaluer rapidement les conséquences d'un désastre afin de planifier et d'organiser l'assistance aux populations sinistrées, ainsi qu'à évaluer à court et à long terme l'efficacité et la pertinence des mesures prises. Une série d'indices sont décrits et discutés. Pour ce qui est des décès, plusieurs indices sont préconisés: taux des décès constituant un effet immédiat du désastre, taux de décès spécifiques par groupe d'âge, taux de décès selon le type d'habitat, rapport 
entre le nombre des décès et celui des maisons détruites, et tendances de la mortalité au cours des jours qui suivent la catastrophe. En ce qui concerne la morbidité, le rapport entre le nombre des blessés et celui des morts - qui atteint un niveau plus élevé dans les tremblements de terre - de même que le pourcentage des blessés par rapport à la population totale et la distribution des divers types de lésion, peuvent fournir des éléments importants pour la planification des secours. Les statistiques des consultations dans les centres médicaux les jours qui suivent la catastrophe et la distıibution des causes invoquées, de même que le taux de recours aux services offerts - notamment l'occupation des lits d'hôpitaux avec l'origine géographique des malades hospitalisés - fournissent des éléments très utiles pour l'organisation des secours à plus long terme. Les chiffres d'incidence des maladies transmissibles sont, pour leur part, essentiels à l'instauration d'un système de surveillance et de lutte. Ces divers indices sont discutés à la lumière d'exemples récents. Etant donné l'importance d'une évaluation épidémiologique rapide de la situation créée par les désastres, la constitution d'équipes polyvalentes capables de s'en charger offre un champ d'action particulièrement prometteur pour la collaboration internationale. 